\title{
Therapeutic effects of stemonine on particulate matter 2.5-induced chronic obstructive pulmonary disease in mice
}

\author{
JINBO ZHANG $^{1}$, SHIQING LI $^{2}$, LI SUN $^{3}$, YANXIA CHEN $^{4}$, LEI ZHANG $^{5}$ and ZHENGHUI ZHANG ${ }^{1}$ \\ ${ }^{1}$ Center for Preventive Treatment of Disease; Departments of ${ }^{2}$ Encephalopathy, ${ }^{3}$ Gynecology and Obstetrics, ${ }^{4}$ Rehabilitation \\ and ${ }^{5}$ Heart Disease, Yantai Hospital of Traditional Chinese Medicine, Yantai, Shandong 264016, P.R. China
}

Received November 17, 2016; Accepted June 6, 2017

DOI: $10.3892 / \mathrm{etm} .2017 .5092$

\begin{abstract}
Particulate matter $2.5\left(\mathrm{PM}_{2.5}\right)$ is a growing concern worldwide due to its association with respiratory diseases, including chronic obstructive pulmonary disease (COPD). Stemonine, a traditional Chinese herb, has been demonstrated to exhibit anti-inflammatory and antioxidant properties, making it a potential drug for the treatment of respiratory diseases. The therapeutic effects of stemonine on mice with $\mathrm{PM}_{2.5}$-induced COPD were investigated in the present study. Kunming mice were randomly divided into the following five groups ( $n=10 /$ group): Control, model, low-dose stemonine, moderate-dose stemonine and high-dose stemonine. The model mice received an intranasal instillation of $\mathrm{PM}_{2.5}$ suspension (40 mg/kg). The levels of specific enzymes, markers of oxidative stress, and the inflammatory cytokines tumor necrosis factor (TNF)- $\alpha$ and interleukin (IL)- 6 were measured in the bronchoalveolar lavage fluid of the mice using ELISA kits. Hematoxylin and eosin staining was performed to determine inflammatory changes to the lung tissue. It was demonstrated that stemonine could significantly alleviate lung injury by decreasing the levels of enzymes and cytokines associated with inflammation and oxidative stress in a dose-dependent manner. In addition, stemonine dose-dependently increased the amount of superoxide dismutase. These results suggest that stemonine reduces lung inflammation in mice with $\mathrm{PM}_{2.5}$-induced COPD, providing a novel approach for the treatment of $\mathrm{PM}_{2.5}$-induced respiratory diseases.
\end{abstract}

\section{Introduction}

A contaminated atmospheric environment, including that in numerous Chinese regions suffering from fog and haze, has a serious impact on human health. The increasing levels of

Correspondence to: Dr Jinbo Zhang, Center for Preventive Treatment of Disease, Yantai Hospital of Traditional Chinese Medicine, 39 Xingfu Road, Yantai, Shandong 264016, P.R. China E-mail: jinbozhang2016@126.com

Key words: lung lavage, chronic obstructive pulmonary disease, particulate matter 2.5, stemonine mortality and morbidity due to lung infection and respiratory diseases are attributed to elevated levels of particulate matter (PM), particularly small inhalable particles like $\mathrm{PM}_{2.5}$ (1).

$\mathrm{PM}_{2.5}$ is a type of $\mathrm{PM}$ that is $\leq 2.5 \mu \mathrm{m}$ in diameter. The physical damage caused by PM is associated with its size; the smaller the size, the greater damage it causes. In addition, $\mathrm{PM}_{2.5}$ accumulates toxic heavy metals, acid oxides, organic pollutants, bacteria and viruses in the air, $\mathrm{PM}_{2.5}$ can also remain in the air for a long time and be deposited in the lungs through inhalation, so it is a major threat to human health $(2,3)$. Numerous previous studies have suggested that $\mathrm{PM}_{2.5}$ can stimulate the production of reactive oxygen species (ROS) and certain inflammatory mediators, resulting in changes to vascular permeability, airway constriction and tissue injury (4-6). The majority of previous studies investigating $\mathrm{PM}_{2.5}$ have histopathologically examined lung sections $(7,8)$.

Chronic obstructive pulmonary disease (COPD) is characterized by airway obstruction due to the destruction of lung parenchyma, structural alterations of the small airways and systemic inflammation (9). COPD is a major cause of morbidity and mortality globally, and knowledge about its pathogenesis has increased substantially over the past decade $(9,10)$. The primary risk factor for COPD is prolonged cigarette smoking (11). Another risk factor for COPD is chronic environmental exposure to toxic atmospheric pollutants, including PM (2-4). Several mechanisms of action have been proposed for the anti-inflammatory efficacy of antibiotics and traditional Chinese medicines (TCMs) on respiratory diseases, including COPD, house dust mite-induced allergic asthma, resistance of Klebsiella pneumoniae, and ventilator-associated pneumonia (12-15). However, the efficacy of such antibiotics was limited by their side effects in clinical trials, which included vomiting, diarrhea, weight loss and headaches (16-18). At present, no effective control measures have been developed for the treatment of $\mathrm{PM}_{2.5}$-induced respiratory diseases apart from reducing $\mathrm{PM}_{2.5}$ emissions, wearing a dust respirator and increasing the number of plants. Therefore, novel medicines with fewer side effects and a high efficacy for treating $\mathrm{PM}_{2.5}$-induced respiratory diseases are required.

A TCM extracted from Stemona tuberosa, stemonine, has been applied for insecticidal and medicinal purposes (19). S. tuberosa is found in certain regions of Japan and China, and its root can be used to obtain stemonine. In TCM it is believed that the external use of stemonine deters mosquitoes and that 
its oral administration can relieve a cough. In previous studies, several types of stemonine were used to treat chronic lung diseases, including chronic bronchitis, pneumonia, asthma and COPD, through antibacterial action, resolving phlegm and relaxing bronchial smooth muscle (20-22).

In the present study, the effects of stemonine and its mechanism of action were investigated in mice with $\mathrm{PM}_{2.5}$-induced COPD. The results revealed that stemonine attenuated acute $\mathrm{PM}_{2.5}$-induced lung inflammation by inhibiting the infiltration of inflammatory cells. These results suggest that stemonine is a potential candidate for the treatment of respiratory diseases.

\section{Materials and methods}

Animals and reagents. A total of 50 adult male Kunming mice aged 6-8 weeks and weighing 20-22 g were housed in a pathogen-free environment with a $12 \mathrm{~h}$ light/dark cycle at room temperature $\left(20 \pm 2^{\circ} \mathrm{C}\right)$ with a relative humidity of $50-70 \%$. All animal protocols were conducted in accordance with the Declaration of Helsinki and the Guide for the Care and Use of Laboratory Animals. The present study was approved by the Ethics Committee of Yantai Hospital of Traditional Chinese Medicine (Yantai, China).

All chemicals and solvents used were of analytical grade. The lactate dehydrogenase (LDH, m1002267), alkaline phosphatase (AKP, ml002235), acidic phosphatase (ACP, m1037464), albumin (ALB, m1037889), nitric oxide (NO, m1022390), nitric oxide synthase (NOS, ml001884), malonyldialdehyde (MDA, m1016824) and superoxide dismutase (SOD, m1001998) ELISA kits were obtained from Shanghai Enzyme-Linked Biotechnology Co., Ltd. (Shanghai, China) and used according to the manufacturer's protocol.

Source and separation of $\mathrm{PM}_{2.5}$. Urban airborne $\mathrm{PM}_{2.5}$ was collected with a Thermo Anderson sampler (PDR-1500; Thermo Fisher Scientific, Inc., Waltham, MA, USA) in Yantai, China for 2 consecutive weeks in January 2016. Subsequently, the sampling filter membrane was cut into $3 \times 2 \mathrm{~cm}$ sections and immersed in ultrapure water for ultrasonic oscillation (room temperature; $100 \mathrm{kHz}$; four times, $30 \mathrm{~min}$ each). After filtration with gauze, the filtrate was centrifuged at $16,060 \mathrm{x} \mathrm{g}$ for $20 \mathrm{~min}$ at room temperature. After centrifugation, the supernatant was removed and the precipitation was collected into physiological saline (PS), autoclave-sterilized, freeze-dried and stored at $4^{\circ} \mathrm{C}$ until required.

COPD model establishment and administration. The model mice $(\mathrm{n}=40)$ received intranasal instillation of $20 \mu \mathrm{l}$ of $\mathrm{PM}_{2.5}$ suspension $(40 \mathrm{mg} / \mathrm{kg}$ ) once a day for 7 consecutive days, whereas mice in the control group $(n=10)$ received the same amount of PS. The model mice were then randomly divided into the following four groups ( $n=10 /$ group): Model group (40 mg/kg PM P.. ), low-dose stemonine (LS) treatment group (45 mg/kg stemonine), moderate-dose stemonine (MS) treatment group ( $90 \mathrm{mg} / \mathrm{kg}$ stemonine) and the high-dose stemonine (HS) treatment group (180 $\mathrm{mg} / \mathrm{kg}$ stemonine). Stemonine was obtained from Beijing Kangrentang Pharmaceutical Co. (Beijing, China; batch no. 15009731). The treatment period lasted for 21 days, with treatment occurring once daily. All of the mice were checked daily for their general condition including physical appearance and behavior of mice, including hair condition, liveliness, sensitivity and respiratory murmur. A total of $24 \mathrm{~h}$ after the last intranasal instillation, the mice were sacrificed. The left upper lobe of the lungs was removed for hematoxylin and eosin (H\&E) staining, and bronchoalveolar lavage fluid (BALF) and lung specimens were collected for further analysis.

BALF analysis. BALF was obtained by injecting $1 \mathrm{ml}$ of $1 \mathrm{X}$ PBS and withdrawing as much fluid as possible according to the procedure used by Chen et al (13). BALF was then centrifuged at $200 \mathrm{x}$ g for $10 \mathrm{~min}$ at $4^{\circ} \mathrm{C}$. The obtained supernatants were used to detect the levels of LDH, AKP, ACP, ALB, NO, NOS, MDA and SOD with the aforementioned kits according to the manufacturer's protocol. Levels of the cytokines tumor necrosis factor (TNF)- $\alpha$ and interleukin (IL)-6 in the BALF were analyzed using ELISA kits according to the manufacturer's protocol (H052 and H007; Nanjing Jiancheng Bioengineering Institute, Nanjing, China).

Lung histology. The lung samples (left upper lobe of the lungs) from each group were fixed with $10 \%$ buffered formalin solution at room temperature for $24 \mathrm{~h}$. The fixed lung tissues were dehydrated, embedded in paraffin and sectioned $(5 \mu \mathrm{m})$. H\&E staining was performed at room temperature for 5-10 min each to determine inflammatory changes to the lung tissue. The specimens were then examined using light microscopy for the effects of inflammation, including infiltrates, thickened alveolar septae, pus and cell hyperplasia.

Statistical analysis. Comparisons between groups were analyzed by one-way analysis of the variance followed by Fisher's least significant difference test. Results are expressed as the mean \pm standard deviation. $\mathrm{P}<0.05$ was considered to indicate a statistically significant difference.

\section{Results}

Stemonine improves the physical appearance and behavior of mice with $P M_{2.5}$-induced COPD. Throughout the experimental period, mice in the control group had shiny hair, and were lively and sensitive, whereas the COPD model mice exhibited shaggy hair, and appeared listlessness and unresponsive, in addition to having a respiratory murmur (data not shown). Furthermore, the mean body weight of the LS, MS and HS groups was higher compared with that of the model group (data not shown).

Stemonine decreases pulmonary inflammation in mice with $P M_{2.5}$-induced COPD. To evaluate the effect of stemonine on the biomembrane and parenchyma in the lungs of the mice, biochemical markers in the BALF were measured, including LDH, ACP, AKP and ALB (Fig. 1 and Table I). Compared with the control group mice that received PS, the model mice that received $\mathrm{PM}_{2.5}$ had significantly higher levels of $\mathrm{LDH}$, ACP, AKP and ALB (all $\mathrm{P}<0.05$ ), indicating more pulmonary inflammation. However, the groups treated with stemonine $(45,90$ and $180 \mathrm{mg} / \mathrm{kg})$ exhibited a significant decrease in $\mathrm{LDH}, \mathrm{ACP}, \mathrm{AKP}$ and ALB compared with the model group $($ all $\mathrm{P}<0.05)$. These results suggest that stemonine has a 
Table I. Stemonine decreases the levels of LDH, ACP, AKP and ALB in mice with particulate matter 2.5-induced chronic obstructive pulmonary disease.

Enzyme/protein investigated

\begin{tabular}{lcccc}
\cline { 2 - 4 } Group & LDH $(\mathrm{U} / \mathrm{l})$ & ACP $(\mathrm{U} / \mathrm{l})$ & AKP $(\mathrm{U} / \mathrm{l})$ & ALB $(\mathrm{mg} / \mathrm{ml})$ \\
\hline Control & $112.975 \pm 6.562$ & $1.642 \pm 0.136$ & $4.653 \pm 0.247$ & $0.064 \pm 0.023$ \\
Model & $405.634 \pm 18.693^{\mathrm{a}}$ & $3.854 \pm 0623^{\mathrm{a}}$ & $8.795 \pm 0.312^{\mathrm{a}}$ & $0.198 \pm 0.264^{\mathrm{a}}$ \\
LS & $314.564 \pm 8.126^{\mathrm{a}, \mathrm{b}}$ & $3.101 \pm 0282^{\mathrm{a}, \mathrm{b}}$ & $7.582 \pm 0.196^{\mathrm{a}, \mathrm{b}}$ & $0.159 \pm 0.132^{\mathrm{a}, \mathrm{b}}$ \\
MS & $221.721 \pm 9.124^{\mathrm{a}, \mathrm{b}}$ & $2.551 \pm 0362^{\mathrm{a}, \mathrm{b}}$ & $6.538 \pm 0.264^{\mathrm{a}, \mathrm{b}}$ & $0.105 \pm 0.067^{\mathrm{a}, \mathrm{b}}$ \\
HS & $125.623 \pm 8.643^{\mathrm{a}, \mathrm{b}}$ & $2.002 \pm 0328^{\mathrm{a}, \mathrm{b}}$ & $5.315 \pm 0.169^{\mathrm{a}, \mathrm{b}}$ & $0.079 \pm 0.153^{\mathrm{a}, \mathrm{b}}$ \\
\hline
\end{tabular}

LDH, lactate dehydrogenase; ACP, acidic phosphatase; AKP, alkaline phosphatase; ALB, albumin; LS, low-dose stemonine; MS, moderate-dose stemonine; HS, high-dose stemonine. ${ }^{\mathrm{a}} \mathrm{P}<0.05$ vs. the control group; ${ }^{\mathrm{b}} \mathrm{P}<0.05$ vs. the model group.
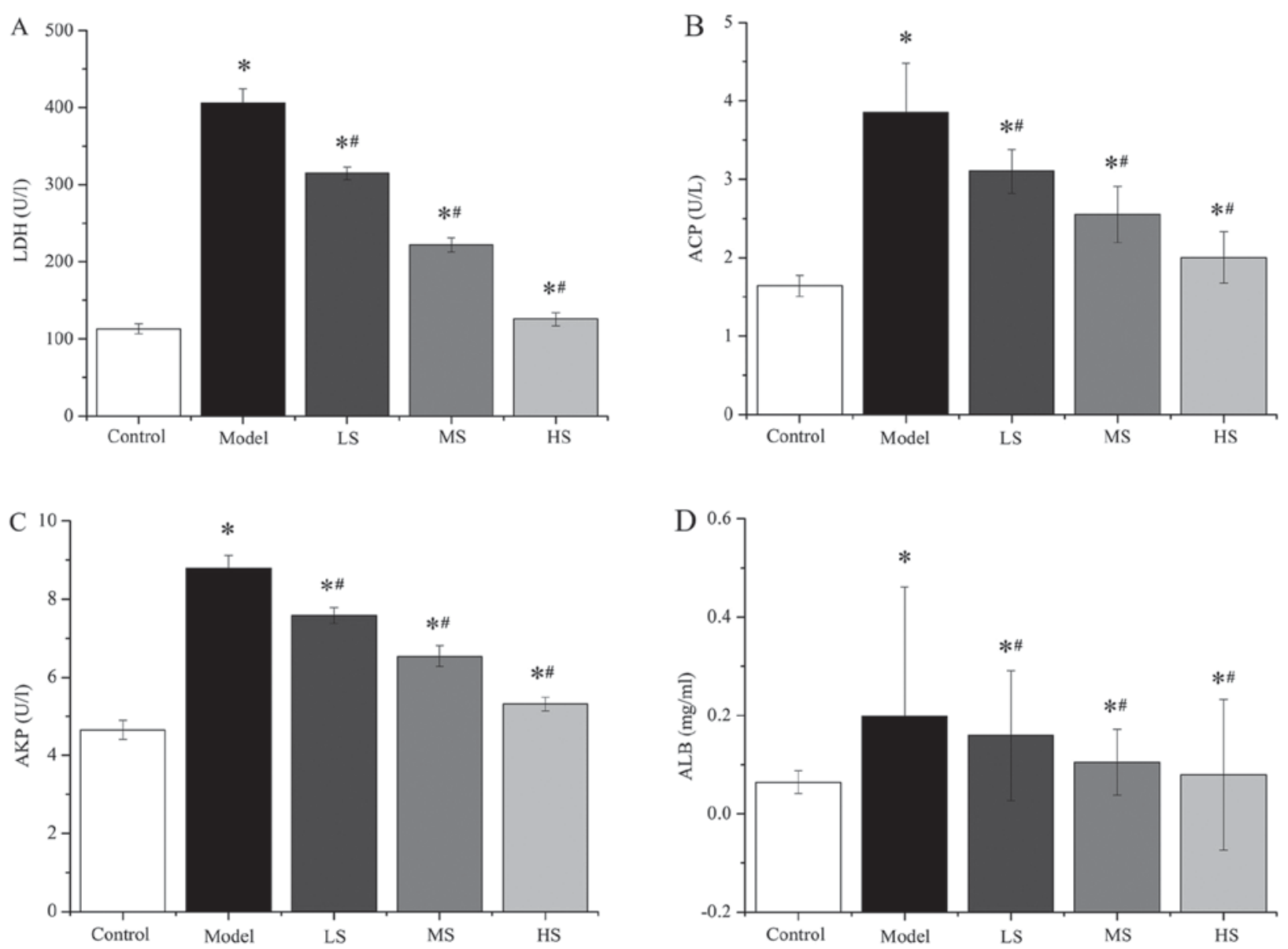

Figure 1. Stemonine decreases the levels of LDH, ACP, AKP and ALB in mice with particulate matter 2.5-induced chronic obstructive pulmonary disease. Levels of (A) LDH, (B) ACP, (C) AKP and (D) ALB in the bronchoalveolar fluid. LDH, lactate dehydrogenase; ACP, acidic phosphatase; AKP, alkaline phosphatase; ALB, albumin; LS, low-dose stemonine; MS, moderate-dose stemonine; HS, high-dose stemonine. ${ }^{*} \mathrm{P}<0.05$ vs. the control group; ${ }^{\sharp} \mathrm{P}<0.05$ vs. the model group.

dose-dependent negative effect on the levels of LDH, ACP, AKP and ALB.

Stemonine decreases the levels of oxidative stress markers in mice with $P M_{2.5}$-induced COPD. The activity of SOD and NOS, and the amount of NO and MDA were measured in the BALF of the different groups using ELISA kits (Fig. 2 and Table II). SOD activity was measured through the reduction of xanthine oxidase to uric acid and $\mathrm{H}_{2} \mathrm{O}_{2}$, which reduces nitroblue tetrazolium (NBT) to NBT-formazan (23). The activity of NOS, and the levels of NO and MDA in the LS, MS and HS groups was significantly decreased compared with the model group (all $\mathrm{P}<0.05$ ). In addition, the activity of SOD was significantly increased in the LS, MS and HS groups compared with the model group $(\mathrm{P}<0.05)$. These data indicate that stemonine inhibits the oxidative stress induced by $\mathrm{PM}_{2.5}$ in the lungs of 
Table II. Stemonine decreases the levels of MDA. NO and NOS, and increases the level of SOD, in mice with particulate matter 2.5-induced chronic obstructive pulmonary disease.

Marker of cellular oxidation state

\begin{tabular}{lcccc}
\cline { 2 - 4 } Group & MDA $(\mathrm{nmol} / \mathrm{ml})$ & NO $(\mu \mathrm{mol} / \mathrm{l})$ & NOS $(\mathrm{U} / \mathrm{ml})$ & SOD $(\mathrm{U} / \mathrm{ml})$ \\
\hline Control & $0.729 \pm 0.098$ & $4.219 \pm 0.494$ & $2.783 \pm 0.147$ & $26.895 \pm 0.891$ \\
Model & $1.791 \pm 0.524^{\mathrm{a}}$ & $13.712 \pm 0.628^{\mathrm{a}}$ & $5.962 \pm 0.135^{\mathrm{a}}$ & $13.246 \pm 0.628^{\mathrm{a}}$ \\
LS & $1.568 \pm 0.319^{\mathrm{a}, \mathrm{b}}$ & $11.597 \pm 0.352^{\mathrm{a}, \mathrm{b}}$ & $4.983 \pm 0.103^{\mathrm{a}, \mathrm{b}}$ & $16.163 \pm 0.52^{\mathrm{a}, \mathrm{b}}$ \\
MS & $1.335 \pm 0.208^{\mathrm{a}, \mathrm{b}}$ & $8.846 \pm 0.523^{\mathrm{a}, \mathrm{b}}$ & $3.893 \pm 0.136^{\mathrm{a}, \mathrm{b}}$ & $19.682 \pm 0.424^{\mathrm{a}, \mathrm{b}}$ \\
HS & $1.165 \pm 0.128^{\mathrm{a}, \mathrm{b}}$ & $7.471 \pm 0.493^{\mathrm{a}, \mathrm{b}}$ & $3.013 \pm 0.114^{\mathrm{a}, \mathrm{b}}$ & $23.936 \pm 0.431^{\mathrm{a}, \mathrm{b}}$ \\
\hline
\end{tabular}

MDA, malonyldialdehyde; NO, nitric oxide; NOS, NO synthase; SOD, superoxide dismutase; LS, low-dose stemonine; MS, moderate-dose stemonine; HS, high-dose stemonine. ${ }^{\mathrm{a}} \mathrm{P}<0.05$ vs. the control group; ${ }^{\mathrm{b}} \mathrm{P}<0.05$ vs. the model group.
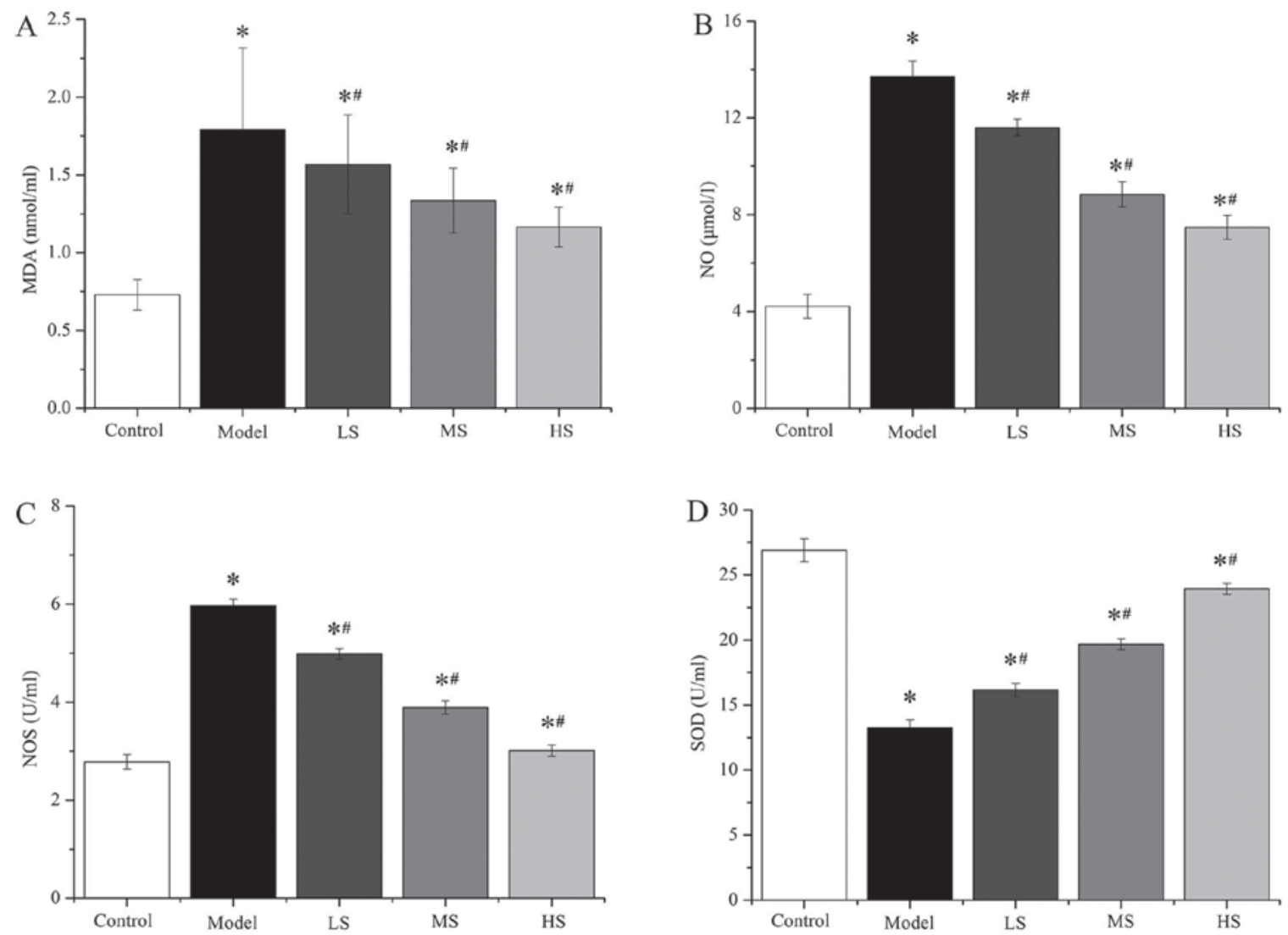

Figure 2. Stemonine decreases the levels of MDA. NO and NOS, and increases the level of SOD, in mice with particulate matter 2.5 -induced chronic obstructive pulmonary disease. Levels of (A) MDA, (B) NO, (C) NOS and (D) SOD in the bronchoalveolar fluid. MDA, malonyldialdehyde; NO, nitric oxide; NOS, NO synthase; SOD, superoxide dismutase; LS, low-dose stemonine; MS, moderate-dose stemonine; HS, high-dose stemonine. "P<0.05 vs. the control group; ${ }^{\text {"}} \mathrm{P}<0.05$ vs. the model group.

mice in a dose-dependent manner, thus reducing oxidative stress-associated lung damage.

Stemonine alleviates lung inflammation in mice with $P M_{2.5}$-induced COPD. Previous studies have demonstrated that acute cigarette smoke exposure depletes the antioxidant capacity of the lungs $(24,25)$. Thus, the effects of stemonine on the levels of the cytokines TNF- $\alpha$ and IL- 6 in the BALF of the different groups were measured using ELISA kits in the present study (Fig. 3 and Table III). The levels of TNF- $\alpha$ and IL- 6 in the groups treated with stemonine $(45,90$ and $180 \mathrm{mg} / \mathrm{kg}$ ) were significantly higher compared with those in the control group (all $\mathrm{P}<0.05$ ), whereas they were significantly lower compared with the model group (all $\mathrm{P}<0.05$ ). These results suggest that stemonine alleviates $\mathrm{PM}_{2.5}$-induced lung inflammation in mice.

Stemonine reduces lung inflammation and damage in mice with $P M_{2.5}$-induced COPD. Histology analysis was performed and evaluated as previously described $(23,24)$. Pathological 

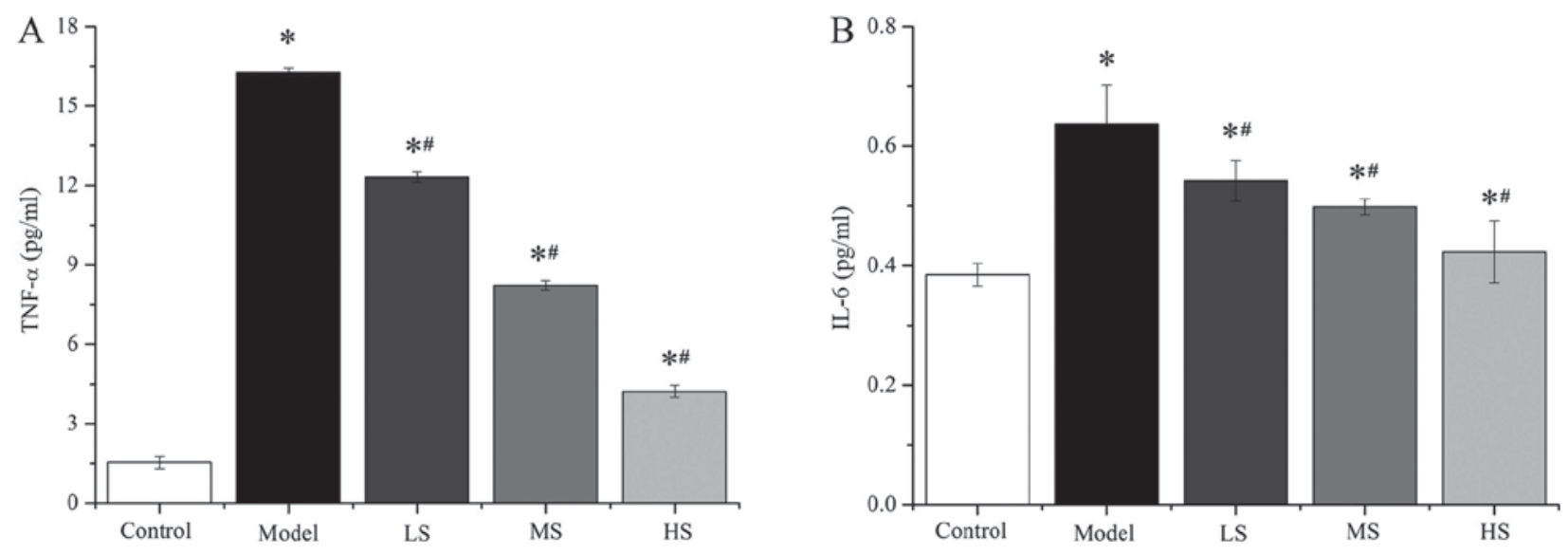

Figure 3. Stemonine decreases of the levels of TNF- $\alpha$ and IL-6 in mice with particulate matter 2.5 -induced chronic obstructive pulmonary disease. Levels of (A) TNF- $\alpha$ and (B) IL-6 in the bronchoalveolar fluid. TNF- $\alpha$, tumor necrosis factor $\alpha$; IL-6, interleukin 6; LS, low-dose stemonine; MS, moderate-dose stemonine; HS, high-dose stemonine; A, absorbance. ${ }^{*} \mathrm{P}<0.05$ vs. the control group; ${ }^{\prime} \mathrm{P}<0.05$ vs. the model group.

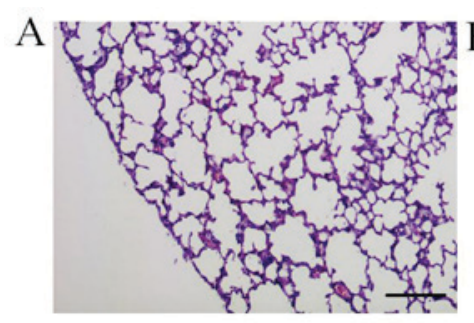

Control

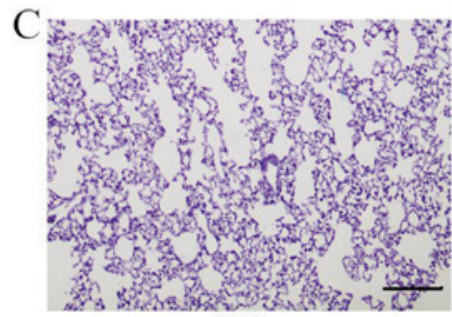

LS

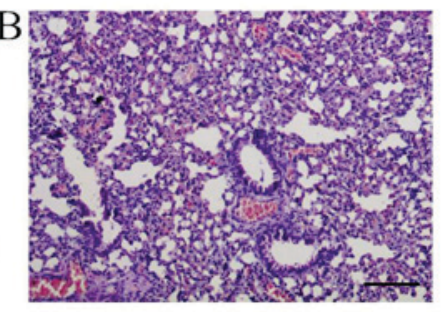

Model

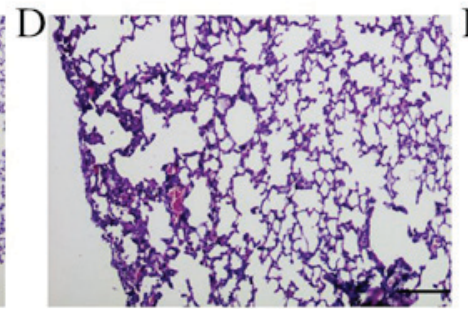

MS

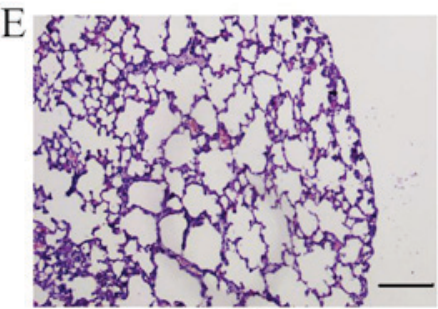

HS

Figure 4. Stemonine reduced inflammatory changes in the lung tissue of mice with particulate matter 2.5-induced chronic obstructive pulmonary disease. Histopathological findings of hematoxylin and eosin-stained lungs specimens in the (A) control, (B) model, (C) LS, (D) MS and (E) HS groups. Magnification, x100; scale bar, $100 \mu \mathrm{m}$. LS, low-dose stemonine; MS, moderate-dose stemonine; HS, high-dose stemonine.

Table III. Stemonine decreases of the levels of TNF- $\alpha$ and IL-6 in mice with particulate matter 2.5-induced chronic obstructive pulmonary disease.

\begin{tabular}{lcc}
\hline & \multicolumn{2}{c}{ Cytokine } \\
\cline { 2 - 3 } Group & TNF- $\alpha(\mathrm{pg} / \mathrm{ml})$ & $\mathrm{IL}-6(\mathrm{pg} / \mathrm{ml})$ \\
\hline Control & $1.54 \pm 0.24$ & $0.385 \pm 0.019$ \\
Model & $16.25 \pm 0.19^{\mathrm{a}}$ & $0.637 \pm 0.065^{\mathrm{a}}$ \\
LS & $12.31 \pm 0.19^{\mathrm{a}, \mathrm{b}}$ & $0.542 \pm 0.034^{\mathrm{a}, \mathrm{b}}$ \\
MS & $8.23 \pm 0.17^{\mathrm{a}, \mathrm{b}}$ & $0.498 \pm 0.013^{\mathrm{a}, \mathrm{b}}$ \\
HS & $4.23 \pm 0.24^{\mathrm{a}, \mathrm{b}}$ & $0.423 \pm 0.052^{\mathrm{a}, \mathrm{b}}$ \\
\hline
\end{tabular}

TNF- $\alpha$, tumor necrosis factor $\alpha$; IL-6, interleukin 6; LS, low-dose stemonine; MS, moderate-dose stemonine; HS, high-dose stemonine; A, absorbance. ${ }^{\mathrm{a}} \mathrm{P}<0.05$ vs. the control group; ${ }^{\mathrm{b}} \mathrm{P}<0.05$ vs. the model group. changes and the effects of inflammation, including infiltrates, thickened alveolar septae, pus and cell hyperplasia, were investigated in the lung tissues of the different groups using H\&E staining (Fig. 4). This revealed marked infiltration of inflammatory cells and exudative changes in the lungs of the model group (Fig. 4B), whereas no inflammation was observed in the control mice (Fig. 4A). However, there was a notable improvement in inflammation in the mice treated with stemonine (Fig. 4C-E) in a dose-dependent manner. These results indicate that stemonine reduces $\mathrm{PM}_{2.5}$-induced lung inflammation and damage, suggesting that it may have a therapeutic effect on the pathological effects of $\mathrm{PM}_{2.5}$.

\section{Discussion}

In recent decades, much research has been focused on the direct and indirect toxic effects of $\mathrm{PM}_{2.5}$ in China, the USA and certain European countries. A previous study reported that PM 
in the air, particularly $\mathrm{PM}_{2.5}$, can cause bronchial wall thickening and the production of ROS (26). Long-term exposure to high levels of PM is associated with respiratory diseases. A previous study reported that $\mathrm{PM}_{2.5}$ exacerbates chronic inflammatory conditions of the lungs, including COPD, pulmonary hypertension and autoimmune diseases (25). With increasing $\mathrm{PM}_{2.5}$ in the air, the incidence of respiratory diseases, including pneumonia, asthma and COPD, will gradually increase.

Recently, several types of TCMs have been used to treat $\mathrm{PM}_{2.5}$-induced respiratory diseases (27-29). A recent study reported that tuberostemonine could attenuate acute cigarette smoke-induced inflammation of the lung via inhibiting the infiltration of inflammatory cells through decreasing chemokine expression (30). Chen et al (13) reported that resveratrol exhibits potent antiallergic activities on allergic airway inflammation in a house dust mite-induced mouse model of asthma. Qin et al (31) identified that Guben Zhike granules could reduce inflammatory cell infiltration and improve lung function in a $\mathrm{PM}_{2.5}$-induced mouse model of lung injury. Other studies have explored the underlying mechanisms of allergic airway inflammation and pulmonary hypertension associated with environmental toxins, for example, nasal inoculation of particulate matter (PM2.5) could induce allergic airway inflammation in NC/Nga mice (4), and Park et al (32) identified B cells and antigen specific IgG1 as potential therapeutic targets for pulmonary hypertension associated with immune dysfunction and environmental exposures. The present study demonstrated that stemonine, which is derived from $S$. tuberose, exhibits therapeutic effects on mice with $\mathrm{PM}_{2.5}$-induced COPD. An influx of inflammatory cells, and changes to the lung tissue and alveolar structure, were observed when the mice were exposed to $\mathrm{PM}_{2.5}$. However, when these mice were treated with stemonine it inhibited the influx of inflammatory cells.

Several previous studies have demonstrated that $\mathrm{PM}_{2.5}$ exposure directly activates innate immune cells and epithelial cells, and induces chemokine, proinflammatory cytokine, growth factor, protease and antibacterial protein expression $(28,33,34)$. To investigate the underlying molecular mechanisms of the effects of $\mathrm{PM}_{2.5}$, the present study analyzed the levels of specific enzymes, oxidative stress markers and cytokines in the BALF, in addition to performing histology analysis. This revealed significantly increased levels of $\mathrm{LDH}$, ACP, AKP, ALB, MDA, NO, NOS, TNF- $\alpha$ and IL-6, and significantly decreased levels of SOD, in the BALF after exposure to $\mathrm{PM}_{2.5}$. This indicates that $\mathrm{PM}_{2.5}$ exerts its effects through altering the expression of cytokines and increasing ROS production in the lungs. In addition, stemonine treatment significantly decreased the levels of LDH, AKP, ACP, ALB, NO, NOS, MDA, TNF- $\alpha$ and IL-6, and significantly increased the level of SOD, in a dose-dependent manner. These data indicate that stemonine attenuates acute $\mathrm{PM}_{2.5}$-induced lung inflammation via inhibiting the infiltration and cytotoxicity of inflammatory cells. Therefore, stemonine is a potential therapeutic drug for the treatment of respiratory diseases.

Since $\mathrm{PM}_{2.5}$ is a complex mixture of various components, and the composition of $\mathrm{PM}_{2.5}$ collected at different time points and in different locations varies, the mechanisms by which $\mathrm{PM}_{2.5}$ functions in the body is likely to be complex. The present study was a preliminary investigation into the therapeutic effects of stemonine on immunoreactivity and oxidative stress in a mouse model of $\mathrm{PM}_{2.5}$-induced lung injury. Future research should explore other mechanisms of $\mathrm{PM}_{2.5}$ in lung injury, and the interaction and mutual associations between these mechanisms. In addition, the specific regulation of the mechanism by which $\mathrm{PM}_{2.5}$ functions remains to be elucidated. Furthermore, studies should aim to identify the essential targets of stemonine, which could lead to the pharmacological development of treatments for respiratory diseases induced by $\mathrm{PM}_{2.5}$.

In conclusion, stemonine is able to inhibit the development of $\mathrm{PM}_{2.5}$-induced lung inflammation through inhibition of the cytokine response, thus making it a therapeutic candidate for the treatment of respiratory diseases, including COPD. At present, no effective control measures have been developed for the treatment of $\mathrm{PM}_{2.5}$-induced respiratory diseases apart from reducing $\mathrm{PM}_{2.5}$ emissions, wearing a dust respirator and increasing the number of plants. The results of the present study highlight novel areas for the prevention and treatment of respiratory diseases associated with environmental pollution.

\section{References}

1. Kaiser J: Air pollution: Evidence mounts that tiny particles can kill. Science 289: 22-23, 2000.

2. Zhao Q, He KB, Ma YL, Jia YT, Cheng Y, Liu H and Wang SW: Regional PM pollution in Beijing and surrounding area during summertime. Huan Jing Ke Xue 30: 1873-1880, 2009 (In Chinese).

3. Pope CA III, Burnett RT, Thun MJ, Calle EE, Krewski D, Ito K and Thurston GD: Lung cancer, cardiopulmonary mortality and long-term exposure to fine particulate air pollution. JAMA 287: $1132-1141,2002$.

4. Kodavanti UP, Jaskot RH, Su WY, Costa DL, Ghio AJ and Dreher KL: Genetic variability in combustion particle-induced chronic lung injury. Am J Physiol 272: L521-L532, 1997.

5. Tong Y, Ni X, Zhang Y, Chen F, Zhang G and Ye S: Study of toxicological mechanism of acidified aerosols. Biol Trace Elem Res 85: 149-156, 2002.

6. Ogino K, Zhang R, Takahashi H, Takemoto K, Kubo M, Murakami I, Wang DH and Fujikura Y: Allergic airway inflammation by nasal inoculation of particulate matter (PM2.5) in NC/Nga mice. PloS One 9: e92710, 2014.

7. Dye JA, Lehmann JR, McGee JK, Winsett DW, Ledbetter AD, Everitt JI, Ghio AJ and Costa DL: Acute pulmonary toxicity of particulate matter filter extracts in rats: Conherence with epidemiologic studies in Utah valley residents. Environ Health Perspect 109 (Suppl 3): S395-S403, 2001.

8. Greenwell LL, Moreno T, Jones TP and Richards RJ: Particleinduced oxidative damage is ameliorated by pulmonary antioxidants. Free Radic Biol Med 32: 898-905, 2002.

9. Cazzola M, Donner CF and Hanania NA: One hundred years of chronic obstructive pulmonary disease (COPD). Respir Med 101: 1049-1065, 2007.

10. Bozarth AL, Covey A, Gohar A and Salzman G: Chronic obstructive pulmonary disease: Clinical review and update on consensus guidelines. Hosp Pract 42: 79-91, 2014.

11. Kammerl IE, Dann A, Mossina A, Brech D, Lukas C, Vosyka O, Nathan P, Conlon TM, Wagner DE, Overkleeft HS, et al: Impairment of immunoproteasome function by cigarette smoke and in chronic obstructive pulmonary disease. Am J Respir Crit Care Med 193: 1230-1241, 2016.

12. Stefan MS, Rothberg MB, Shieh MS, Pekow PS and Lindenauer PK: Association between antibiotic treatment and outcomes in patients hospitalized with acute exacerbation of COPD treated with systemic steroids. Chest 143: 82-90, 2013.

13. Chen J, Zhou H, Wang J, Zhang B, Liu F, Huang J, Li J, Lin J, Bai J and Liu R: Therapeutic effects of resveratrol in a mouse model of HDM-induced allergic asthma. Int Immunopharmacol 25: 43-48, 2015.

14. Xiao XQ, Lai J, Luo YL, Wang HB, Fang YL and Huang SF: Study on reversal of effect of double coptis in vivo on the resistance of Klebsiella pneumoniae. J Gannan Med Univ 36: 190-192, 2016 (In Chinese). 
15. Zhang F: Clinical observation on treating ventilator-associated pneumonia with the Qingjin Huatan decoction. Clin J Chin Med 8: 71-72, 2016 (In Chinese).

16. Wright $\mathbf{J}$ and Paauw DS: Complications of antibiotic therapy. Med Clin North Am 97: 667-679, 2013.

17. Blumenthal KG, Shenoy ES, Hurwitz S, Varughese CA, Hooper DC and Banerji A: Effect of a drug allergy educational program and antibiotic prescribing guideline on inpatient clinical providers antibiotic prescribing knowledge. J Allergy Clin Immunol Pract 2: 407-413, 2014

18. Rolain JM, Abat C, Jimeno MT, Fournier PE and Raoult D: Do we need new antibiotics? Clin Microbiol Infect 22: 408-415, 2016.

19. Xu YT, Shaw PC, Jiang RW, Hon PM, Chan YM and But PP: Antitussive and central respiratory depressant effects of Stemona tuberosa. J Ethnopharmacol 128: 679-684, 2010.

20. Gao JF and Zhang XY: Experimental observation on germicidal efficacy of a herbal compound disinfectant solution. Chin J Disinfection 22: 305-306, 2005.

21. Chung HS, Hon PM, Lin G, But PP and Dong H: Antitussive activity of Stemona alkaloids from Stemona tuberose. Planta Med 69: 914-920, 2003.

22. Liao JF, Shi CC, Chen SY, Fu YT and Chen CF: Spasmolytic effect of walter extract of Stemonae radix on the guinea-pig tracheal smooth muscle in vitro. J Ethnopharmacol 57: 57-62, 1997.

23. Wang X, Hai CX, Liang X, Yu SX, Zhang W and Li YL: The protective effects of acanthopanax senticosus, harms aqueous extracts against oxidative stress: Role of Nrf2 and antioxidant enzymes. J Ethnopharmacol 127: 424-432, 2010.

24. Onizawa S, Aoshiba K, Kajita M, Miyamoto Y and Nagai A Platinum nanoparticle antioxidants inhibit pulmonary inflammation in mice exposed to cigarette smoke. Pulm Pharmacol Ther 22: 340-349, 2009

25. Rahman I, Bismas SK and Kode A: Oxidant and antioxidant balance in the airways and airway disease. Eur J Pharmacol 533: 222-239, 2006
26. Driscoll KE: TNFa and MIP-2: Role in particle-induced inflammation and regulation by oxidative stress. Toxicol Lett 112-113: 177-183, 2000.

27. Cui S, He ZZ, Zhu ZW, Sun Z, Xu YT, Wang JL, Bao YY, Ji DY, Liu S, Liu JT, et al: Microfluidic analysis of PM2.5-induced epithelial-mesenchymal transition in human bronchial epithelial 16HBE cells. Microfluid Nanofluidics 19: 263-272, 2015.

28. Jing Y, Zhang H, Cai Z, Zhao Y, Wu Y, Zheng X, Liu Y, Qin Y, $\mathrm{Gu} \mathrm{M}$ and Jin J: Bufei huoxue capsule attenuates PM2.5-induced pulmonary inflammation in mice. Evid Based Complement Alternat Med 2017: 1575793, 2017.

29. Wang H, Song L, Ju W, Wang X, Dong L, Zhang Y, Ya P, Yang C and Li F: The acute airway inflammation induced by PM2.5 exposure and the treatment of essential oils in Balb/c mice. Sci Rep 7: 44256, 2017.

30. Jung KH, Beak H, Park S, Shin D, Jung J, Park S, Kim J and Bae H: The therapeutic effects of tuberostemonine against cigarette smoke-induced acute lung inflammation in mice. Eur J Pharmacol 774: 80-86, 2016.

31. Qin YY, Jing Y, Liu Y, Gu MJ, Jin J, Pan L, Cai Z and Zhang HC: Influence of Guben Zhike Granules on lung function and morphology of lung injury mouse model induced by $\mathrm{PM}_{2.5}$. China J Trad Chin Med Pharm 31: 1028-L1031, 2016 (In Chinese).

32. Park SH, Chen WC, Durmus N, Bleck B, Reibman J, Riemekasten $\mathrm{G}$ and Grunig G: The effects of antigen-specific IgG1 antibody for the pulmonary-hypertension-phenotype and $\mathrm{B}$ cells for inflammation in mice exposed to antigen and fine particles from air pollution. PLoS One 10: e0129910, 2015.

33. Su WY, Jaskot RH, Richards J, Abramson SR, Woessner JF Jr, $\mathrm{Yu}$ WH and Dreher KL: Induction of pulmonary matrilysin expression by combustion and ambient air particles. Am J Physiol Lung Cell Mol Physiol 279: L152-L160, 2000.

34. Veranth JM, Kaser EG, Veranth MM, Koch M and Yost GS: Cytokine responses of human lung cells (BEAS-2B) treated with micron-sized and nanoparticles of metal oxides compared to soil dusts. Part Fibre Toxicol 4: 2, 2007. 